\title{
POTRZEBY I ZACHOWANIA GOŚCIA HOSTELOWEGO NA PRZYKŁADZIE ŁÓDZKICH HOSTELI
}

\section{Wstęp}

Hostele to obiekty, które dynamicznie rozwijają się na rynku polskich usług noclegowych. Są jego stosunkowo młodym segmentem, którego wskaźnik przyrostu miejsc noclegowych w sezonie 2012/2013 wynosił 8,0 (WŁODARCZYK 2014, s. 259). Stanowią one większą konkurencję dla droższych hoteli, pojawiając się $w$ centrach dużych miast. Ich ogromne zróżnicowanie pozwala potencjalnemu gościowi na odnalezienie takiego hostelu, który jak najbardziej spełni jego oczekiwania. Brak kategoryzacji i wymagań z nią związanych daje nieograniczone możliwości każdemu właścicielowi hostelu, który może wyposażyć go według własnych kryteriów. Oferta noclegowa to doskonała propozycja dla każdego, kto chce skorzystać z taniego noclegu w przyjaznej atmosferze i dogodnych warunkach.

W niniejszej pracy podjęto próbę ukazania potrzeb i zachowań gości korzystających z usług hosteli. W tym celu przeprowadzono badania ankietowe w pięciu łódzkich hostelach, które uzupełniono analizą opinii gości poszczególnych hosteli umieszczoną na portalu rezerwacyjnym booking.com. Umożliwiło to wyszczególnienie wymagań i oczekiwań gości hostelowych oraz cech, którymi kierują się przy wyborze miejsca noclegu. Wyróżniono również segmenty gości o podobnych cechach demograficznych, statusie społecznym, motywach przyjazdu, a także zachowaniach i potrzebach. 


\section{Historia powstawania hosteli na świecie}

Historia rozwoju hosteli jest ściśle związana z powstaniem schronisk młodzieżowych, które rozwijały się wspólnie jako jeden typ obiektu noclegowego. Hostele dopiero $\mathrm{z}$ biegiem czasu przekształciły się $\mathrm{w}$ ich odrębny rodzaj i zaczęły działać samodzielnie. W 1912 roku w Niemczech w mieście Altena powstał pierwszy hostel na świecie. Idea tworzenia tanich miejsc noclegowych szybko zaczęła rozszerzać się $\mathrm{w}$ innych krajach, dzięki czemu w roku 1932 w Amsterdamie utworzono Międzynarodową Federację Schronisk Młodzieżowych (International Youth Hostel Federation - IYHF). Hostele i schroniska młodzieżowe tworzone były specjalnie $\mathrm{z}$ myślą o osobach podróżujących z plecakiem z miasta do miasta, czyli o tzw. backpackerach, którzy pragną jak najwięcej zwiedzić oraz poznać nowych ludzi. Stanowią oni grupę gości o minimalnych wymaganiach dotyczących pobytu, dzięki czemu hostele spełniają ich oczekiwania. Obecnie hostele i schroniska młodzieżowe wyglądają i działają inaczej niż w poprzednim stuleciu. Stanowią oddzielne grupy obiektów noclegowych, które łączy nie tylko nazwa (youth hostel - schronisko młodzieżowe), ale także wspólny cel jakim jest zapewnienie taniego noclegu dla młodych ludzi. $Z$ racji niskiego standardu, jaki oferują znane w Polsce schroniska młodzieżowe, słowem „hostel" przyjęło się określać niedawno powstałe obiekty, które przyjmując podobnych gości oferują jednak znacznie wyższy standard. Polskie hostele na ogół nie odbiegają standardem od spotykanych w Europie Zachodniej, różnią się natomiast ceną - są dużo tańsze.

Usługi świadczone $\mathrm{w}$ tego typu obiektach scharakteryzowano $\mathrm{w}$ definicji GUS, która wyjaśnia, że jest to obiekt noclegowy o standardzie różniącym się od obiektów hotelowych głównie liczbą miejsc noclegowych w pokojach, występowaniem łóżek piętrowych i współdzieleniem części wyposażenia oraz pomieszczeń przeznaczonych dla gości (np. wspólna kuchnia/łazienka). Podstawą funkcjonowania hostelu jest wynajmowanie łóżka a nie pokoju. Pokoje $w$ hostelach nazywane są powszechnie dormami, czyli pokojami wieloosobowymi. Podobnie M. MILEWSKA i B. WŁODARCZYK $(2015$, s. 140) określili cechę charakterystyczną hostelu, jaką jest wynajmowanie łóżka a nie pokoju oraz niska cena w stosunku do usług świadczonych w hotelach. Nocleg oferowany jest w pokojach koedukacyjnych, męskich lub żeńskich posiadających 6-12 łóżek. Standardem w hostelach jest recepcja czynna przez całą dobę, salon dla gości wraz z telewizorem, ogólnodostępny darmowy internet oraz kawa i herbata. 


\section{Miejsce hosteli w bazie noclegowej Łodzi}

Początki tworzenia bazy noclegowej Łodzi przypadają na okres dynamicznego rozwoju miasta w XIX wieku, będącego następstwem wielkokapitalistycznego rozwoju przemysłu włókienniczego. Za pierwszy, najważniejszy obiekt uważa się powstały w 1853 roku najstarszy hotel, jakim był hotel Polski przy ulicy Piotrkowskiej 3 (MILEWSKA, WŁODARCZYK 2004). Obecnie łódzka baza noclegowa oferuje gościom 7229 miejsc noclegowych rozłożonych w 66 obiektach (tab. 1).

Tab. 1. Liczba obiektów i miejsc noclegowych w Łodzi w 2014 r.

\begin{tabular}{|l|c|c|}
\hline \multicolumn{1}{|c|}{ Rodzaj obiektu } & $\begin{array}{c}\text { Liczba } \\
\text { obiektów }\end{array}$ & Liczba miejsc \\
\hline Hotele & 29 & 4965 \\
\hline Motele & 0 & 0 \\
\hline Pensjonaty & 0 & 0 \\
\hline Inne obiekty hotelowe & 14 & 883 \\
\hline Domy wycieczkowe & 3 & 298 \\
\hline Schroniska & 0 & 0 \\
\hline Schroniska młodzieżowe & 2 & 0 \\
\hline Ośrodki wczasowe & 0 & 0 \\
\hline Ośrodki kolonijne & 0 & 504 \\
\hline Ośrodki szkoleniowo-wypoczynkowe & 0 & 0 \\
\hline Hostele & $\mathbf{8}$ & 70 \\
\hline Domy pracy twórczej & 0 & 0 \\
\hline Zespoły domków turystycznych & 1 & 80 \\
\hline Kempingi & 0 & 0 \\
\hline Pola biwakowe & 1 & 212 \\
\hline Zakłady uzdrowiskowe & 0 & 7229 \\
\hline Pozostałe obiekty niesklasyfikowane & 3 & \\
\hline Ogółem & 66 & 0 \\
\hline
\end{tabular}

Źródło: opracowanie własne na podstawie danych z www.stat.gov.pl.

Najwięcej miejsc noclegowych (4965 - 69\%) znajduje się w 29 hotelach $(43 \%)$. Na drugim miejscu ze swoją ofertą znalazły się inne obiekty hotelowe $^{1}(14-21 \%)$ z 883 miejscami noclegowymi (12\%). Następne są hostele

${ }^{1}$ Obiekt noclegowy, podzielony na pokoje, podlegający jednemu zarządowi, świadczący pewne usługi, w tym przynajmniej codzienne sprzątanie pokoi, słanie łóżek i mycie urządzeń sanitarnych (np. obiekt spełniający zadania hotelu, motelu lub pensjonatu, któremu nie została nadana kategoria) (GUS). 
(8-12\%) oferujące 504 miejsca noclegowe (7\%). Dodatkowo w Łodzi funkcjonują trzy domy wycieczkowe (5\%) z 298 miejscami noclegowymi (4\%), trzy pozostałe to obiekty niesklasyfikowane z 212 miejscami noclegowymi (3\%), dwa schroniska młodzieżowe (3\%) dające 121 miejsc noclegowych $(2 \%)$ oraz po jednym (2\%) polu biwakowym z 80 miejscami noclegowymi $(2 \%)$ i zespole domków turystycznych z 70 miejscami noclegowymi (1\%). Nie odnotowano żadnych moteli, pensjonatów, schronisk, ośrodków wczasowych, kolonijnych, szkoleniowo-wypoczynkowych, domów pracy twórczej, kempingów, zakładów uzdrowiskowych.

Tab. 2. Wykorzystanie bazy noclegowej w Łodzi w latach 2008-2011

\begin{tabular}{|c|c|c|c|c|c|c|c|c|c|c|c|c|}
\hline \multirow{3}{*}{$\begin{array}{l}\text { Rodzaj } \\
\text { obiektu }\end{array}$} & \multicolumn{4}{|c|}{ Polacy } & \multicolumn{4}{|c|}{ Cudzoziemcy } & \multicolumn{4}{|c|}{ Ogółem } \\
\hline & 2008 & 2009 & 2010 & 2011 & 2008 & 2009 & 2010 & 2011 & 2008 & 2009 & 2010 & 2011 \\
\hline & \multicolumn{12}{|c|}{ procent } \\
\hline Hotel & 48,2 & 51,7 & 33,0 & 44,7 & 77,0 & 90,5 & 48,1 & 50,6 & 52,5 & 54,4 & 36,8 & 45,8 \\
\hline Pensjonat & 0,7 & 0,5 & 0,9 & 0,9 & 0,9 & 0 & 0 & 0,6 & 0,8 & 14,6 & 0,7 & 0,9 \\
\hline Motel & 0,4 & 1,0 & 0,4 & 0,3 & 0 & 0,9 & 0 & 0 & 0,4 & 14,6 & 0,3 & 0,2 \\
\hline U znajomych & \multirow{2}{*}{11,6} & 16,6 & 21,0 & 16,8 & \multirow{2}{*}{12,9} & 5,4 & 13,3 & 13,4 & \multirow{2}{*}{11,8} & 9,4 & 19,0 & 16,1 \\
\hline U rodziny & & 12,4 & 17,2 & 14,2 & & 0 & 14,9 & 17,4 & & 6,4 & 16,6 & 14,8 \\
\hline $\begin{array}{l}\text { Dom } \\
\text { wycieczkowy }\end{array}$ & 0,1 & 0,3 & 0,4 & 0,7 & 0 & 0 & 0 & 0 & 0,07 & 3,5 & 0,3 & 0,5 \\
\hline Hostel & 0,3 & 6,0 & 8,3 & 6,2 & 1,4 & 0,9 & 8,3 & 5,2 & 0,5 & 3,2 & 8,3 & 6,0 \\
\hline $\begin{array}{l}\text { Schronisko } \\
\text { młodzieżowe }\end{array}$ & 2,0 & 4,9 & 14,0 & 6,2 & 1,4 & 0,9 & 6,6 & 0 & 1,9 & 2,7 & 12,1 & 5,1 \\
\hline $\begin{array}{l}\text { Własny dom/ } \\
\text { mieszkanie }\end{array}$ & 0,3 & 4,9 & 2,5 & 3,4 & 0,5 & 0 & 3,3 & 4,7 & 0,4 & 2,5 & 2,7 & 3,7 \\
\hline $\begin{array}{l}\text { Dom } \\
\text { studencki }\end{array}$ & - & 1,3 & 0,8 & 1,5 & - & 1,8 & 1,1 & 2,9 & - & 0,9 & 0,8 & 1,2 \\
\hline $\begin{array}{l}\text { Kwatera } \\
\text { prywatna }\end{array}$ & 1,3 & 1,0 & 1,7 & 2,9 & 0,5 & 0,9 & 4,4 & 4,7 & 1,2 & 0,7 & 2,4 & 3,2 \\
\hline Inne * & 35,0 & 2,1 & 0,6 & 2,2 & 5,5 & 0,9 & 1,1 & 0,6 & 30,6 & 0,9 & 1,6 & 1,9 \\
\hline
\end{tabular}

Objaśnienia: * Kemping/pole namiotowe, mieszkanie pracownicze, wynajęte mieszkanie.

Źródło: opracowanie własne na podstawie danych z: www.rot.pl, S. LISZEWSKI (red. 2010) i B. WŁODARCZYK( red. 2011, 2012).

O dużym znaczeniu hosteli w łódzkiej bazie noclegowej świadczą wyniki badań ankietowych przeprowadzonych na terenie miasta oraz $\mathrm{w}$ miejscach atrakcyjnych turystycznie wśród turystów krajowych i zagranicznych. Wyniki te zaprezentowane zostały $\mathrm{w}$ raportach $\mathrm{z} 2008$ roku zamieszczonych na portalu Regionalnej Organizacji Turystycznej Województwa Łódzkiego 
(www.rot.pl) przygotowanych przez Małopolską Organizację Turystyczną (Ruch turystyczny w Łodzi w 2008 r., Ruch turystyczny w województwie tódzkim w 2008 r.) oraz w raportach (LISZEWSKI, red. 2010, WŁODARCZYK, red. 2011, 2012) przygotowanych przez Regionalną Organizację Turystyczną Województwa Łódzkiego. $\mathrm{W}$ tab. 2 przedstawiono strukturę bazy noclegowej wykorzystanej przez badanych turystów polskich i zagranicznych w latach 2008-2011.

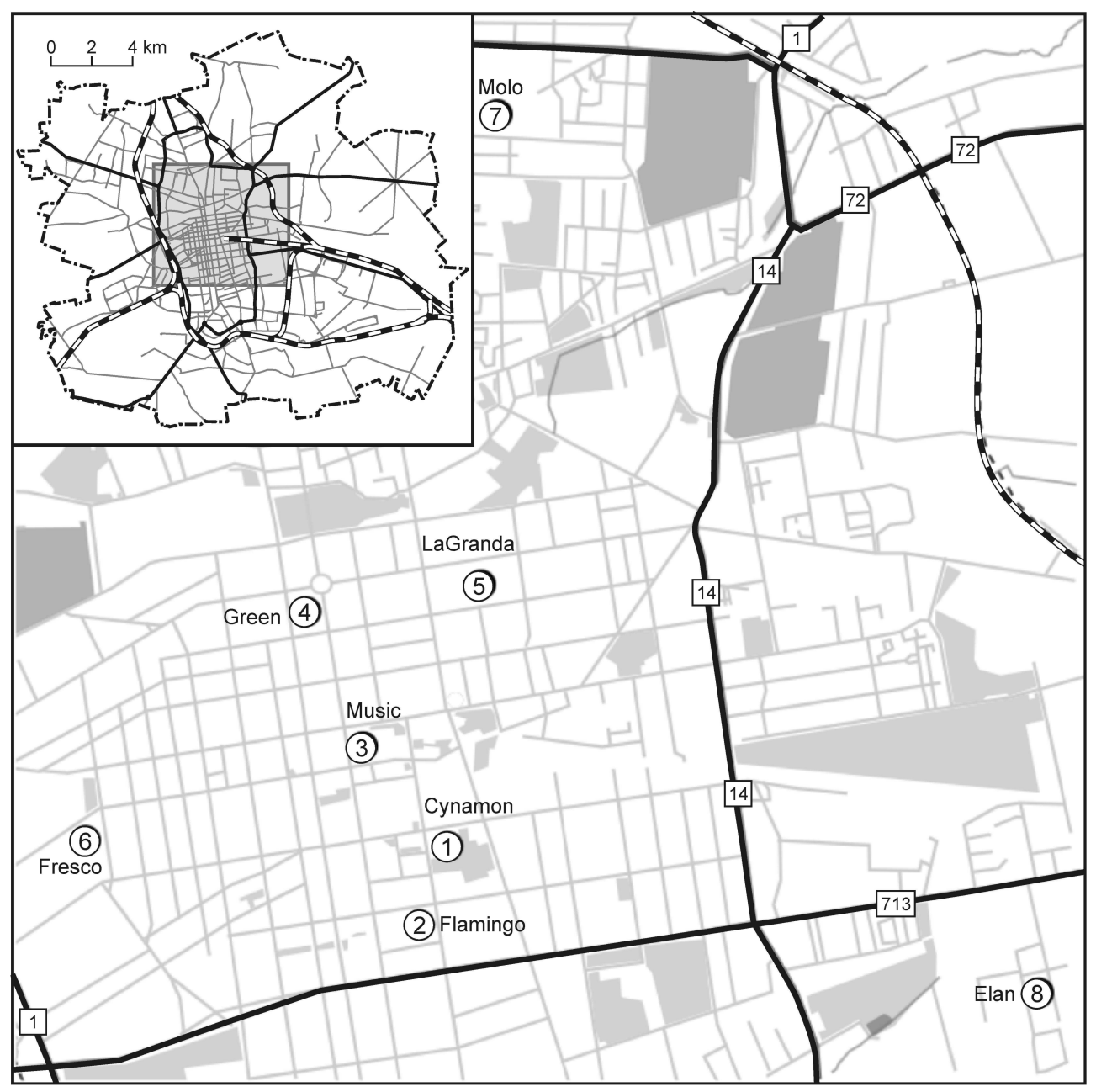

Rys. 1. Rozmieszczenie hosteli w Łodzi Źródło: opracowanie własne 
Hostele w Łodzi zajmowały 8. miejsce w 2008 r., w kolejnych latach awansowały na 4 . miejsce popularności wśród Polaków. Wśród cudzoziemców zajmowały 4 . miejsce przez cały czas badania. $Z$ danych zamieszczonych w tab. 2 widać, że w latach 2008-2011 zmalało wykorzystanie obiektów świadczących usługi o wyższym standardzie: hoteli (52,5\% w 2008 r., 45,8\% w 2011 r.) oraz moteli (0,4\% w 2008, 0,2\% w 2011), a zarazem zwiększyło się wykorzystanie obiektów noclegowych niższego standardu, takich jak: pensjonaty $(0,8 \% \mathrm{w} 2008,0,9 \% \mathrm{w} 2011)$, domy wycieczkowe $(0,1 \% \mathrm{w} 2008,0,5 \%$ w 2011), schroniska młodzieżowe (1,9\% w 2008, 5,1\% w 2011), domy studenckie $(0,9 \%$ w $2009,1,2 \%$ w 2011$)$ oraz kwatery prywatne $(1,2 \%$ w 2008 , $3,2 \%$ w 2011). Dodatkowo częściej zaczęto korzystać z noclegów organizowanych na własną rękę, nocując u znajomych (11,8\% w 2008, 16,1\% w 2011), $\mathrm{u}$ rodziny $(6,4 \% \mathrm{w} 2009,14,8 \% \mathrm{w} 2011)$ oraz we własnym domu/mieszkaniu $(0,4 \%$ w 2008, 3,7\% w 2011). Tendencja ta utrzymywała się zarówno wśród Polaków, jak i cudzoziemców.

W Łodzi, zgodnie z danymi pochodzącymi z GUS oraz z listą obiektów niekategoryzowanych - innych obiektów noclegowych, udostępnioną przez Centrum Informacji Turystycznej, znajduje się osiem hosteli (rys. 1).

Mapa rozmieszczenia hosteli (rys. 1) ukazuje ich lokalizację przede wszystkim w centrum miasta, z czego sześć z nich w bliskiej odległości od głównej ulicy - Piotrkowskiej. Większość gości korzystających z ich usług stanowią studenci oraz osoby podróżujące służbowo, dla których lokalizacja w pobliżu uczelni oraz różnych instytucji jest szczególnie istotna.

\section{Badania opinii gości łódzkich hosteli na portalu booking.com}

Serwis rezerwacyjny booking.com umożliwia gościom wystawienie opinii dopiero po dokonaniu rezerwacji i zakończeniu pobytu, dzięki czemu istnieje pewność, że pochodzą one od gości, którzy naprawdę odwiedzili dany obiekt. Analiza opinii zamieszczonych na tym portalu umożliwiła określenie podstawowych oczekiwań i preferencji, jakimi kierują się goście wybierając swoje miejsce noclegu. Do przeprowadzenia badań wzięto pod uwagę opinie pochodzące z sześciu łódzkich hosteli, które zostały zamieszczone w ciągu 14 miesięcy (styczeń 2015 r. - luty 2016). Łącznie swoje opinie wyraziło 356 osób, wśród których było 186 kobiet (52\%) oraz 170 mężczyzn (48\%). Domi- 
nowały pobyty krótkie, w zdecydowanej większości trwające jedną (73\%), dwie (18\%) oraz trzy doby (5\%) (rys. 2). Wykresy pozwalają dostrzec następującą zależność, że wraz ze wzrostem długości pobytu malała ich liczba.

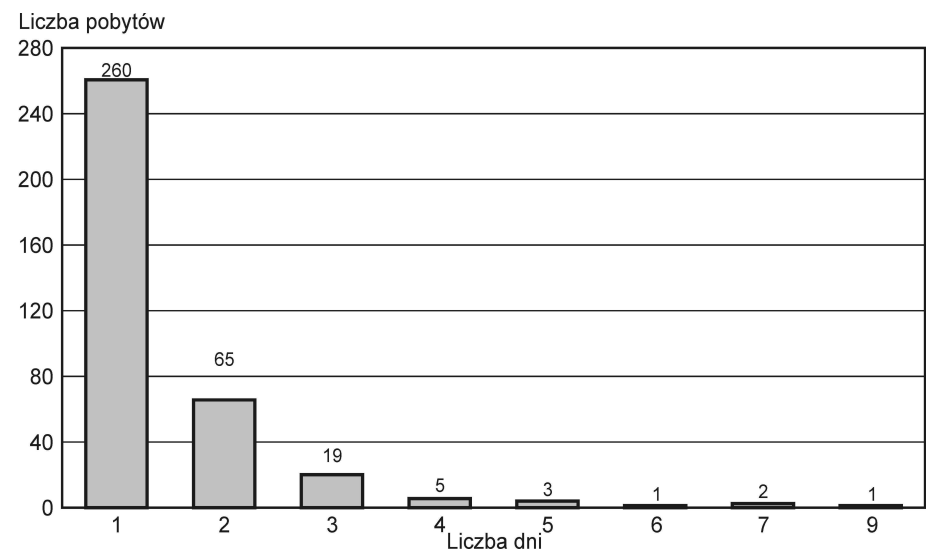

Rys. 2. Długość trwania pobytu gości w łódzkich hostelach Źródło: opracowanie własne

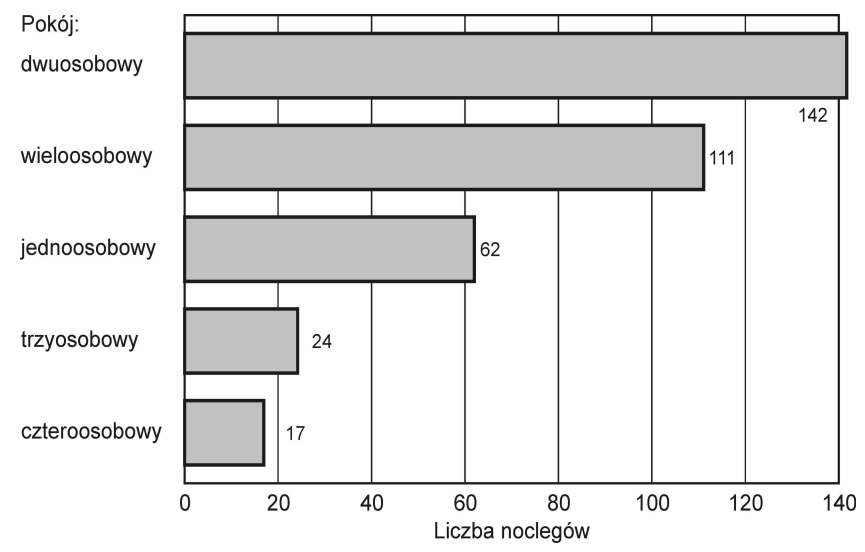

Rys. 3. Wykorzystanie pokoi przez gości łódzkich hosteli Źródło: opracowanie własne

Spośród wszystkich odpowiedzi, jedynie trzy wskazywały na pobyt dłuższy, trwający minimum tydzień. Dwie osoby pozostawały w hostelu siedem dni, jedna dziewięć dni. Najwięcej osób (142 - 40\%) korzystało z noclegu w pokoju dwuosobowym (rys. 3). Na drugim miejscu znalazły się charak- 
terystyczne dla hosteli pokoje wieloosobowe, w których pobyt zadeklarowało 111 osób (31\%). Goście podróżujący pojedynczo często wybierali pokoje prywatne - jednoosobowe $(62-17 \%)$. W trzyosobowym (24 - 7\%) i czteroosobowym $(17-5 \%)$ pokoju nocowały grupy osób, które wspólnie podróżują i wyrażają chęć spania w pokoju wieloosobowym, ale wśród osób, które znają. Goście korzystający z usług hosteli to przede wszystkim osoby, które zostają jedynie na jeden lub dwa dni w mieście. Prawdopodobnie wykorzystują oni hostel jedynie jako miejsce noclegu, realizują jak najszybciej zamierzone cele i wyjeżdżają z miasta. Podróżują najczęściej w parach, wtedy też cenią sobie prywatność i wybierają pokoje niewspółdzielone. Jednak idea tanich noclegów w dormach jest doceniana przez gości. Osoby, które przede wszystkim szukają miejsca do spania $\mathrm{z}$ chęcią korzystały $\mathrm{z}$ tej formy zakwaterowania.

Analiza opinii zamieszczonych na portalu booking.com pozwoliła na wyszczególnienie dziewięciu cech, na które najczęściej zwracają uwagę goście korzystający z usług hosteli. Wybrano te, które wymieniano i komentowano zarówno pozytywnie, jak i negatywnie we wszystkich przebadanych hostelach. Wszystkie z nich są obiektywne, ponieważ udzielano ich dopiero po zakończonym pobycie, dzięki czemu gość miał czas na zweryfikowanie standardu pokoi, jakości posiłków czy życzliwości personelu (rys. 4).

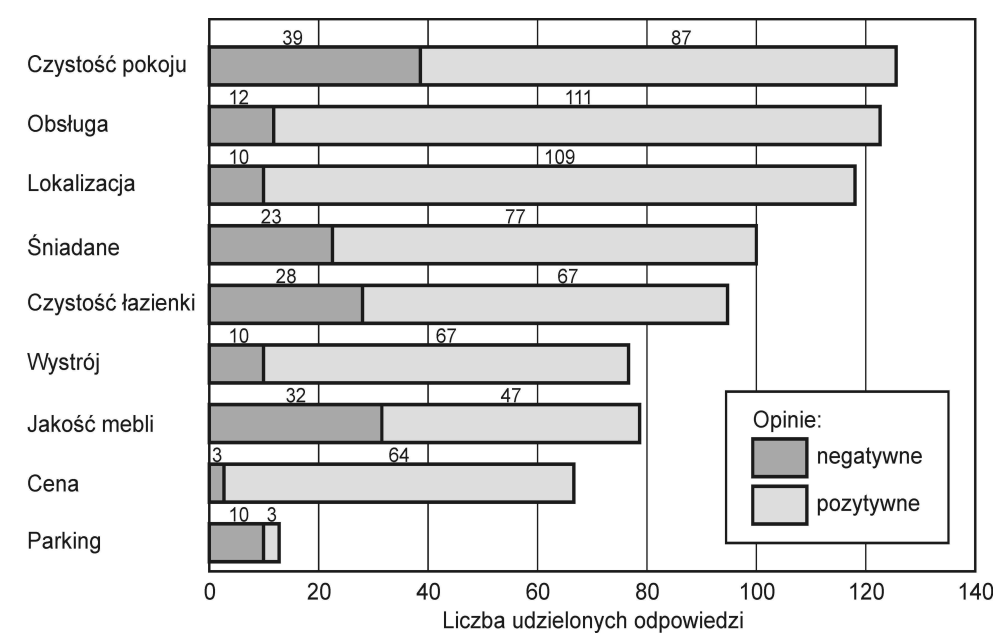

Rys. 4. Opinie gości na temat cech łódzkich hosteli Źródło: opracowanie własne 
Najwięcej osób (126) w swoich opiniach wspominało o czystości pokoju, w którym spali. Większość $(87-69 \%)$ oceniła ją pozytywnie, reszta $(39-31 \%)$ zdecydowała, że warunki te nie spełniły ich oczekiwań, zwracając uwagę na kurz znajdujący się na meblach lub pościel, do której czystości mieli zastrzeżenia. Na drugim miejscu wśród najczęściej komentowanych cech znalazła się ocena obsługi. Wspomniały o niej 123 osoby, wśród których przeważały zdecydowanie pozytywne opinie (111 - 90\%), jedynie 12 osób (10\%) uskarżało się na nieodpowiednie zachowanie personelu. Najczęściej wśród wad wymieniano lenistwo oraz brak chęci niesienia pomocy. Lokalizacja obiektu była trzecim z najważniejszych czynników, które wskazywały na wybór konkretnego hostelu. Cecha ta pojawiła się w 119 opiniach. Zdecydowana większość osób (109 - 91\%) wyrażała się o niej w samych pozytywach, pozostali (10 - 9\%) natomiast narzekali na usytuowanie obiektu przy ruchliwej ulicy bądź w ciemnej bramie. Wielu gości (100) doceniało fakt, że w cenę noclegu wliczone jest również śniadanie. W większości (77 - 77\%) byli oni z niego zadowoleni. Pozostała część badanych (23 - 23\%) uskarżała się na jakość śniadania oraz niedostateczną ilość jedzenia serwowanego przez hostel. Wynikało to ze zdecydowanie zawyżonych oczekiwan, gdyż w standardzie, o którym są goście informowani, znajduje się śniadanie w formie bufetu szwedzkiego z ograniczonym wyborem potraw.

Czystość łazienki w odróżnieniu od czystości pokoju pojawiła się dopiero na 5. miejscu z 96 opiniami. Pozytywnie wyraziło się o niej 67 (71\%) gości, negatywnie zaś 38 (29\%). Nie mieli co do niej tak wysokich oczekiwań, co zapewne wynikało z faktu, że łazienki te znajdują się na korytarzach i może korzystać z nich wiele osób. Na wystrój wskazało 77 gości. Tematycznie urządzone hostele zadowoliły większość z nich (67 - 87\%), jedynie 10 osób (13\%) nie było usatysfakcjonowanych wyglądem wnętrza. W trakcie pobytu zwracano uwagę na jakość mebli i wyposażenia obiektu. Zdania tutaj były bardzo podzielone. Spośród 59 osób 47 (80\%) wyraziło się pozytywnie, 32 (20\%) narzekały na niewygodne łóżka, brak czajnika w pokoju bądź odpryskującą farbę ze ścian. Zaskakującym wynikiem okazało się być wskazanie ceny dopiero na 8. miejscu. Jak się okazuje, nie jest ona czynnikiem, na który w pierwszej kolejności zwracają uwage goście. Są skłonni zapłacić więcej za pobyt, ale chcieliby aby odbył się w lepszych warunkach. Pisało o cenie 67 gości, z czego aż 64 (96\%) wypowiedzi były pozytywne, a jedynie 3 (4\%) negatywne. Parking nie był istotną cechą wyboru hostelu. Spośród jedynie 13 opinii 10 (77\%) było negatywnych. Były to najczęściej słowa niezadowolenia z jego braku. 


\section{Badania usług świadczonych w wybranych łódzkich hostelach}

Badania ankietowe zrealizowano $\mathrm{w}$ pięciu łódzkich hostelach $\mathrm{w}$ terminie sierpień - październik 2015 roku. Respondenci zostali wybrani przez dobór celowy - przeprowadzono 200 ankiet. W efekcie przeprowadzonych badań wyróżniono za pomocą metody grupowania cztery jednorodne wewnętrznie segmenty gości hostelowych, charakteryzujących się podobnymi cechami demograficznymi oraz posiadających określone wymagania dotyczące standardu i jakości oferowanych im usług (MAZURKIEWICZ 2002). Wśród przebadanych 52\% (105 osób) stanowiły kobiety, 48\% (95 osób) mężczyźni. Jako kryterium segmentacji wzięto pod uwagę motywy oraz cele, jakimi kierowali się respondenci przyjeżdżając do Łodzi. Najliczniejszą grupę stanowiły osoby przybywające w związku z podróżami służbowymi (83 - 41\%), następną - w celach wypoczynkowych i poznawczych (52 - 26\%), a kolejną - na studia $(46-23 \%)$. Ostatnia grupa to osoby, które wybrały odpowiedź inne - gdzie wymieniały przyjazdy na zawody, konkursy oraz festiwale $(19-10 \%)$.

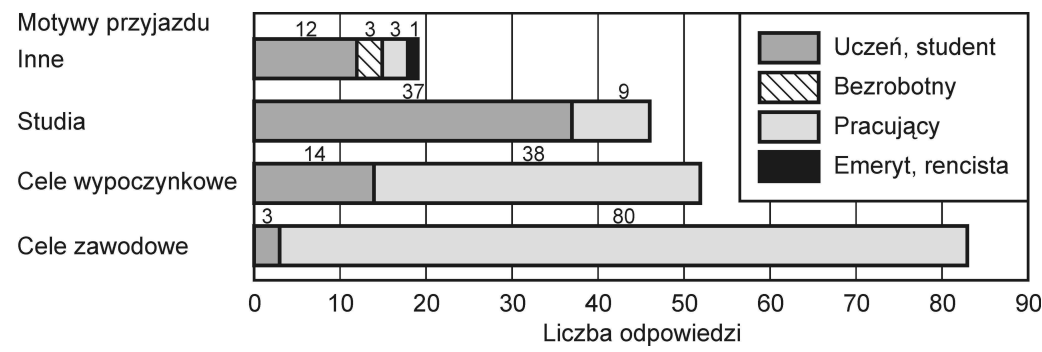

Rys. 5. Motywy przyjazdu oraz status zawodowy gości łódzkich hosteli Źródło: opracowanie własne

Spośród wszystkich osób podróżujących służbowo zdecydowana większość $(80-93 \%)$ to osoby pracujące, które deklarowały przynależność do przedziału wiekowego 30-34 oraz 25-29 lat (rys. 5-6). W swoim czasie wolnym $\mathrm{w}$ celach wypoczynkowych przyjeżdżały głównie osoby pracujące (38-73\%) oraz w mniejszej części studenci (14 - 27\%). Odzwierciedla się to w wybranych przedziałach wiekowych - aż 44\% to osoby w wieku 25-29 lat. Grupę, której głównym motywem były studia, w $80 \%$ stanowili studenci w wieku 20-24 i 25-29 lat. Natomiast na festiwale, zawody i konkursy przyjeżdżali uczniowie $(12-63 \%)$ w wieku $12-19$ lat z opiekunami $(7-37 \%)$, którzy znaleźli się we wszystkich możliwych przedziałach wiekowych. 


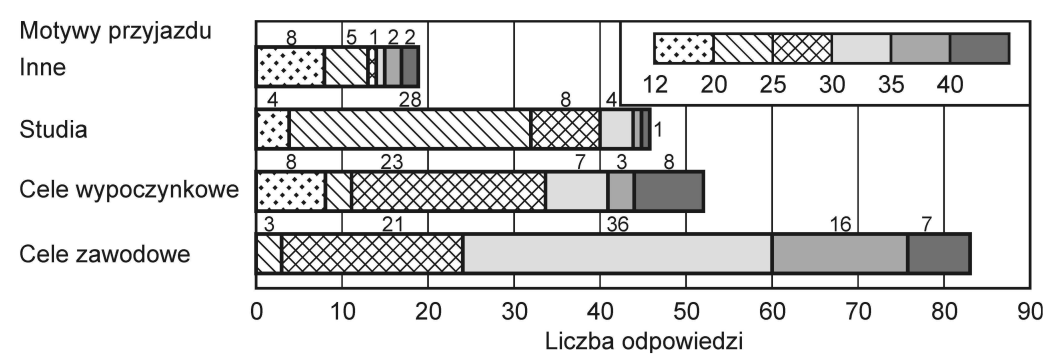

Rys. 6. Motywy przyjazdu oraz wiek gości łódzkich hosteli Źródło: opracowanie własne

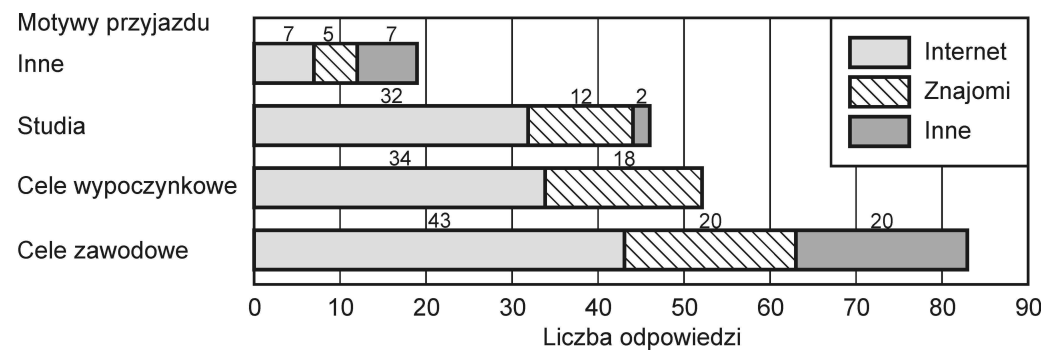

Rys. 7. Motywy przyjazdu do Łodzi oraz źródło informacji na temat hostelu Źródło: opracowanie własne

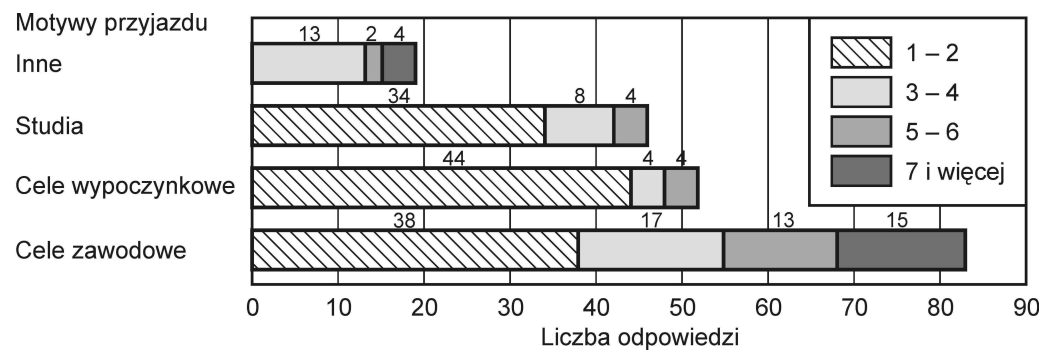

Rys. 8. Motywy przyjazdu do Łodzi oraz długość pobytu gości w hostelu Źródło: opracowanie własne

W każdym segmencie wyraźnie można zauważyć dominację Internetu jako głównego źródła informacji (rys. 7). W mniejszym stopniu decydowano się na hostel pod wpływem polecenia go przez znajomych. Osoby, które wybrały odpowiedź "inne”, brały udział w wyjazdach zorganizowanych nie mając wpływu na wybór obiektu noclegowego. Spośród wszystkich ankietowanych zdecydowana większość gości pozostawała w hostelu jedynie na 1-2 dni (129 - 65\%), dłużej, bo na 3-4 dni jedynie 31 osób (15\%) (rys. 8). Po- 
zostałe pobyty trwające 5-6 dni oraz 7 i więcej, dotyczyły grupy przyjeżdżających w celach zawodowych, którzy korzystali z noclegów w hostelu $\mathrm{w}$ trakcie wykonywania zleceń. Zazwyczaj wracali na weekendy do domu, co wyjaśnia dużą liczbę 5- i 6-dniowych pobytów.

Różnorodność segmentów przejawia się przede wszystkim w pokojach, z których najczęściej korzystają poszczególni goście (rys. 9). Prywatność i spokój najbardziej ceniły osoby podróżujące służbowo, które wybierały pokoje jedno- i dwuosobowe (48 - 58\%). Studenci w większości decydowali się na najtańszy nocleg w pokojach wieloosobowych $(21-46 \%)$. Ci, którzy przyjechali zwiedzać i wypocząć, podobnie jak w przypadku wyjazdów służbowych, wybierali pokoje prywatne jedno- i dwuosobowe (30 - 57\%). Młodzi, będący w Łodzi w związku z zawodami i konkursami, nocowali w prywatnych pokojach wieloosobowych, w grupach w jakich podróżowali $(9-49 \%)$.

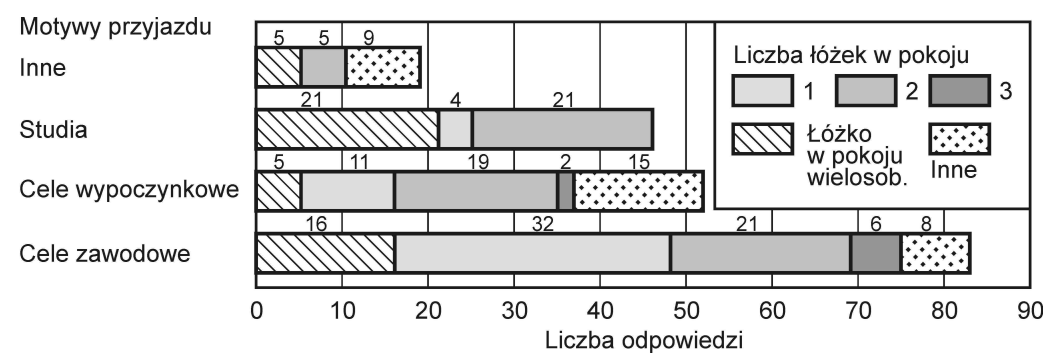

Rys. 9. Motywy przyjazdu do Łodzi oraz rodzaj zakwaterowania gości w hostelu Źródło: opracowanie własne

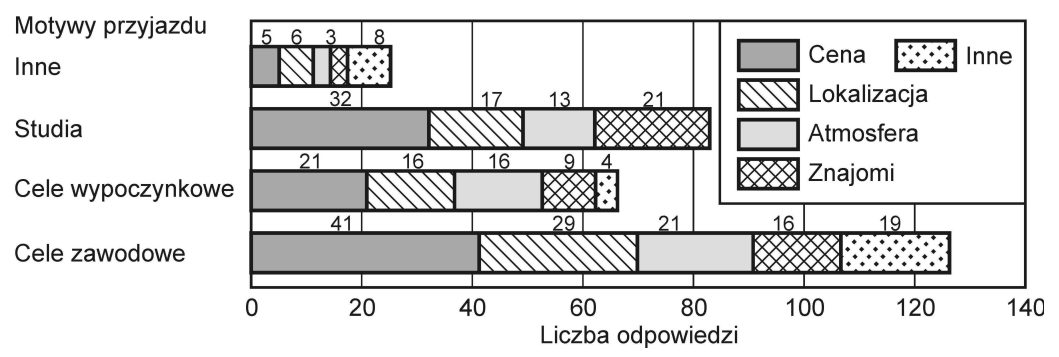

Rys. 10. Motywy przyjazdu do Łodzi oraz czynnik decydujący o wyborze hostelu. Źródło: opracowanie własne

Respondenci na pytanie dotyczące czynników, które zdecydowały o wyborze obiektu, mogli udzielić kilku odpowiedzi (rys. 10). Wśród wszystkich badanych decydującym czynnikiem była cena, którą wybrała prawie połowa 
z nich (99 - 49\%). Była to również cecha charakteryzująca segment osób podróżujących służbowo. Na drugim miejscu wymieniono lokalizację (68 $34 \%)$, a następnie dobrą atmosferę w obiekcie (53 - 27\%).

Ankietowani zostali poproszeni o podanie nazwy miejscowości zamieszkania, co pozwoliło określić zasięg przestrzenny oddziaływania hosteli łódzkich. Spośród wszystkich badanych 21 gości (11\%) wymieniło miejscowość za granicą (w Wielkiej Brytanii, Ukrainie, Litwie, USA). Zasięg przestrzenny gości krajowych zaprezentowano na rys. 11.

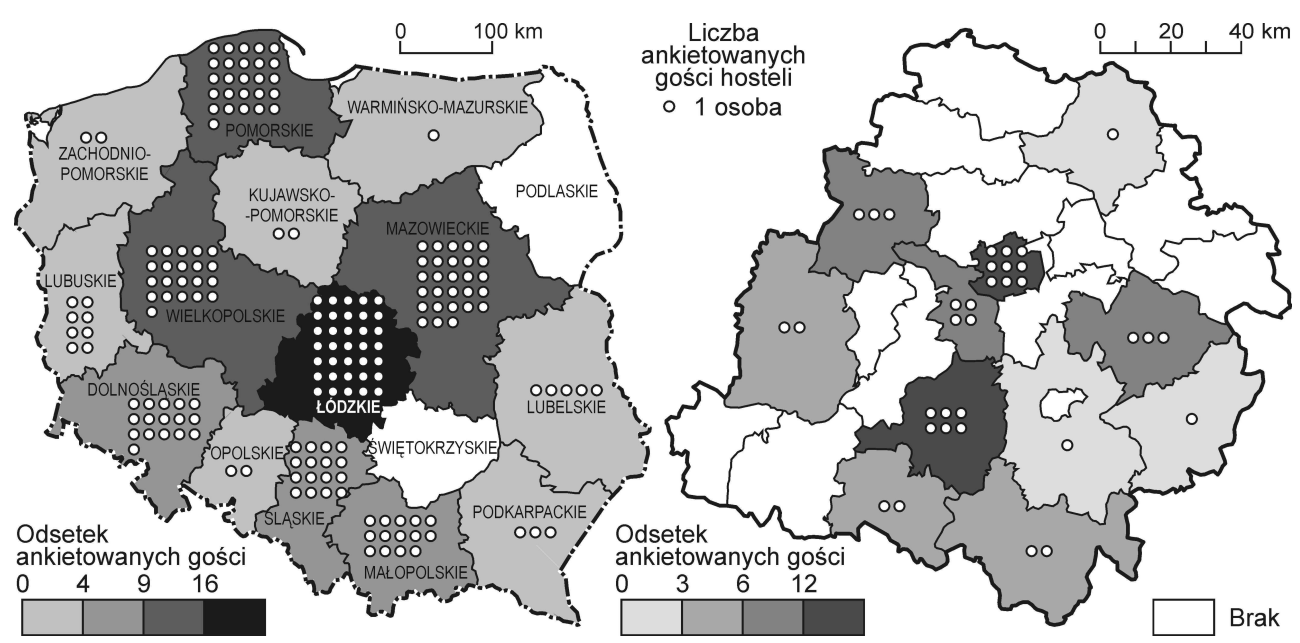

Rys. 11. Zasięg przestrzenny miejsca zamieszkania krajowych gości hosteli łódzkich Źródło: opracowanie własne na podstawie badań ankietowych

Najwięcej osób (35 - 20\%) pochodziło z województwa łódzkiego. Zaskakujący jest fakt, że dominowały osoby z Łodzi (9-26\%). Większość z nich decydowała się na nocleg $\mathrm{w}$ hostelu ze względu na skomplikowaną sytuację rodzinną. Na drugim miejscu znalazły się osoby z powiatu bełchatowskiego (6 - 17\%), następnie kolejno z pabianickiego (4-11\%), po trzy osoby $(9 \%)$ z tomaszowskiego i poddębickiego oraz po dwie osoby (6\%) z pajęczańskiego, radomszczańskiego i sieradzkiego. Najmniej, bo po jednej osobie (3\%) przyjechało z powiatu łowickiego, opoczyńskiego, piotrkowskiego oraz Skierniewic - miasta na prawach powiatu.

Poza województwem łódzkim najwięcej gości przyjechało z sąsiedniego województwa mazowieckiego (28 - 16\%). Duży udział miały również województwa pomorskie $(26-15 \%)$ oraz wielkopolskie (21 - 12\%). Zarówno ze 
śląskiego, jak i dolnośląskiego przyjechało po 16 osób (9\%). Kolejne miejsca zajęły województwa: małopolskie (14 osób - 8\%), lubuskie (8 - 4\%), lubelskie $(5-3 \%)$, podkarpackie $(3-2 \%)$, po dwie osoby (1\%) przyjechały z kujawsko-pomorskiego, opolskiego i zachodniopomorskiego. Najmniejsza liczba gości (1 - 1\%) pochodziła $\mathrm{z}$ warmińsko-mazurskiego. Żaden $\mathrm{z}$ respondentów nie przybył z województwa świętokrzyskiego i podlaskiego.

\section{Podsumowanie}

Hostele jako nowy typ obiektu noclegowego cieszą się coraz większą popularnością. Powstają najczęściej w największych miastach Polski, liczących ponad 500 tys. mieszkańców, czyli np. w Warszawie, Krakowie, Łodzi, Poznaniu oraz we Wrocławiu. W niniejszym opracowaniu scharakteryzowano grupy turystów, którzy korzystają z usług hosteli na przykładzie zachowań gości hosteli łódzkich. Za pomocą segmentacji wykazano, że najwięcej osób w hostelach ceni ich lokalizację, poziom cen oraz przyjemną, domową atmosferę, która najczęściej panuje w tego typu obiektach. Osoby studiujące z chęcią zatrzymywały się w pokojach, które są charakterystyczne dla hosteli, czyli w dormach. Jako osoby młode z przyjemnością integrowały się z innymi, a mniejsza przestrzeń pokoju czy łóżka piętrowe nie stanowiły dla nich żadnego problemu. Byli to najczęściej studenci studiów niestacjonarnych, korzystający z noclegu w weekendy w trakcie kolejnych zjazdów na uczelni. Hostele jako miejsce noclegu bardzo często wybierały również firmy z innych miast. Pracownicy firm budowlanych lub utrzymujących zieleń miasta przyjeżdżali na pobyty dłuższe oraz korzystali z wieloosobowych pokoi. Dla nich istotna była atmosfera i swobodny klimat, jaki panuje w hostelu, gdyż po całym dniu pracy potrzebowali miejsca, w którym można było odpocząć i zregenerować siły. Możliwość tańszego noclegu w pokojach wieloosobowych przyciągała także opiekunów i ich uczniów, którzy grupowo przyjeżdżali na zawody i konkursy. W trakcie pobytu większość gości zwracała dużą uwage na czystość pokoju oraz na poziom obsługi. Życzliwość i pomoc personelu okazała się szczególnie istotna. Wielu z nich doceniło również śniadanie wliczone w cenę noclegu. Zróżnicowanie oferty noclegowej hostelu pozwala na zaspokojenie wielu potrzeb i oczekiwań gości. Brak obowiązku kategoryzacji umożliwia jak najszybsze i najbardziej efektywne dostosowanie obiektu do zmieniających się trendów w hotelarstwie. 


\section{Bibliografia}

LISZEWSKI S. (red.), 2010, Ruch turystyczny w Łodzi i województwie łódzkim w 2009 r., Łódź.

MAZURKIEWICZ L., 2002, Planowanie marketingowe w przedsiębiorstwie turystycznym, Wyd. PWE, Warszawa.

MILEWSKA M., WŁODARCZYK B., 2004, Historia hotelarstwa w Łodzi, „,Turystyka i Hotelarstwo”, 5.

MileWSKA M., WŁODARCZYK B., 2015, Hotelarstwo. Podstawowe wiadomości, Wyd. PWE, Warszawa.

WŁODARCZYK B. (red.), 2011, Ruch turystyczny w Łodzi i województwie łódzkim w 2010 r., Łódź.

WŁODARCZYK B. (red.), 2012, Ruch turystyczny w Łodzi i województwie łódzkim w 2011 r., Łódź.

WŁODARCZYK B., 2014, Baza noclegowa Łodzi i regionu tódzkiego na początku drugiej dekady XXI wieku,

[w:] B. Krakowiak, J. Latosińska (red.), Przeszłość, teraźniejszość i przyszłość turystyki, ser. „Warsztaty z Geografii Turyzmu", 5, Wyd. Uniwersytetu Łódzkiego, Łódź.

www.geoportal.gov.pl; 23.01.2016 r.

www.hihostels.com; 2.02.2016 r.

www.rotwl.pl; 2.02.2016 r.

www.stat.gov.pl; 29.02.2016 r. 